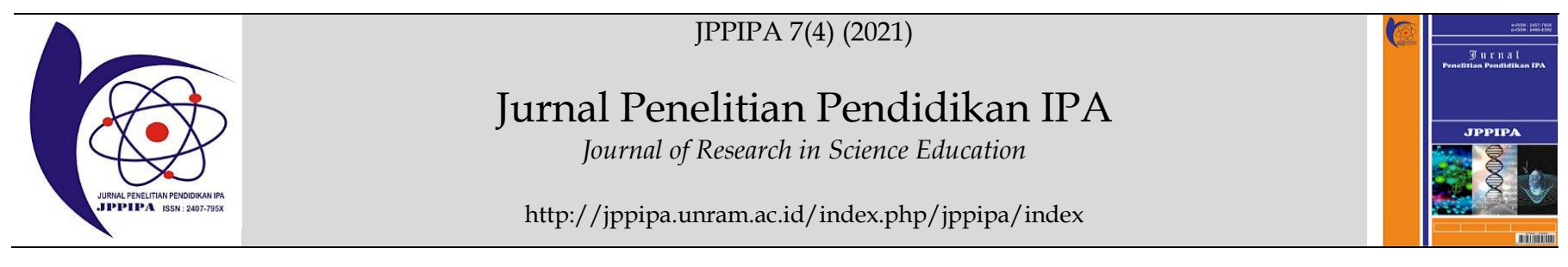

\title{
Application of the Guided Inquiry Model to Improve Science Process Skills High School Students
}

\author{
Ade Rahayu Fadhilla1, Muhibbuddin'2, Muhammad Syukri ${ }^{3 *}$ \\ ${ }^{1}$ Science Education Study Program Postgraduate Program at Syiah Kuala University, Banda Aceh, Indonesia \\ 2 Biology Education Study Program, FKIP, Syiah Kuala University, Banda Aceh, Indonesia \\ ${ }^{3}$ Physics Education Study Program, FKIP, Syiah Kuala University, Banda Aceh, Indonesia
}

DOI: 10.29303/ippipa.v7i4.779

\section{Article Info}

Received : June 3rd, 2021

Revised : August 18th, 2021

Accepted: October 7th, 2021

\begin{abstract}
This study aims to improve students' science process skills by applying a guided inquiry learning model to the concept of work and energy learning physics. The research design used was a quasi-experimental control group design. The population in this study was all class X MIA SMA Negeri 5 Banda Aceh, which consisted of five parallel classes who took the science program in the even semester of 2020/2021 with a total of 139 students. Two classes as the research sample were selected by purposive sampling by taking into account the average value of physics for each class. Meanwhile, the determination of the experimental and control classes in this study was carried out randomly. Data on science process skills in both classes was obtained through observation sheets filled out by two observer teachers. The results of data analysis show that, in general, there is a significant difference between the improvement of science process skills in the experimental class and the control class for the indicators of observing, predicting, measuring, communicating, and concluding. However, for classifying indicators, the results were not significantly different. The improvement of science process skills in the experimental class in general for all of these indicators certainly cannot be separated from each step of the guided inquiry learning model they carry out. The positive results of the implementation of physical learning through the inquiry model on students' science process skills can be used as a reference and support for teacher implementation in carrying out the teaching and learning process of physics, especially on the concept of business and energy.
\end{abstract}

Keywords: Guided Inquiry Model; Science Process Skills; Concept of work and energy.

\begin{abstract}
Citation: Fadhilla, A., Muhibbuddin, M., \& Syukri, M. (2021). Application of the Guided Inquiry Model to Improve Science Process Skills High School Students. Jurnal Penelitian Pendidikan IPA, 7(4), 612-616. doi:https:// doi.org/10.29303/jppipa.v7i4.779
\end{abstract}

\section{Introduction}

Education is a continuous process of learning in social activities to gain knowledge, skills, attitudes, and thinking abilities carried out by a person to develop skills that can later be useful in people's lives (Rosidin et al., 2019). Learning is designed by the teacher to make students actively involved in learning, motivated to learn physics, understand the relationship between the materials being studied, and grow students' science process skills.
Science process skills are scientific thinking skills that are useful for solving problems and formulating results (Lestari \& Diana, 2018). Dwianto et al. (2017) stated that science process skills need to be developed because students can participate actively, train them in learning, and also train them how to think. Wahyuni et al. (2017) revealed that science process skills should be instilled, practiced, and possessed by students because it is the basis for scientific inquiry and intellectual development needed to learn science concepts.

Based on the results of case studies and interviews with teachers at SMA Negeri 5 Banda Aceh, it was

\footnotetext{
*Email: syukri.physics@unsyiah.ac.id
} 
revealed that when evaluating, students were only given questions whose cognitive domains ranged from knowledge and understanding. Students did not understand the physics concepts taught by the teacher, and students rarely did practicum in school. Students' difficulty applying concepts into real stories is not consistent with the concept of the quantity referred to in the problem.

Based on the results of observations, it shows that the learning process in the classroom is still teachercentered, and learning is still in the form of transferring knowledge and factual concepts from teachers to students. Students memorize more physics concepts without understanding the concept. Lack of understanding of the material to be studied. In addition, the learning process in the classroom still uses the lecture and discussion method that does not emphasize the process.

The descriptions that have been presented indicate that students are not used to practicing process skills and lack understanding of students' concepts. Based on the results of interviews with teachers of physics subjects, work and energy are concepts that are difficult for students to understand. Some students still get scores below the minimum completeness criteria from the test scores for the business and energy materials. Only $23 \%$ of the 30 students who meet the Minimum completeness criteria are seven students. The remaining $77 \%$, namely 23 students, are still below the Minimum Completeness Criteria set with a score of 70 .

The description above results in the low Science Process Skills of students. According to Sakdiah et al. (2018), the low student learning outcomes are caused by various factors, one of which is the low Science Process Skills because the learning model used so far has not been able to improve students' Science Process Skills. The indicators used in this study are basic Science Process Skills, including observing, classifying, predicting, measuring, communicating, and concluding.

In connection with the problems described, several ways can overcome these problems, one of which is by changing the learning model because the learning model plays an important role in helping teachers implement the learning process that can improve students' science process skills. One of the learning models that are in accordance with the problems that have been described is the inquiry learning model.

The inquiry model is one of the observation-based learning models (Selviana et al., 2021). This learning will be more meaningful if students are given the opportunity to find facts, build concepts, theories, and principles seen from the environment with teacher guidance so that scientific attitudes emerge in students. Guided inquiry can help students who have problems understanding science process skills in business learning materials and energy because guided inquiry learning is group learning where students are given the opportunity to think independently and help each other with other friends (Gunawan et al., 2019). Guided inquiry learning guides students to have individual responsibility and responsibility in groups or partners. Meanwhile, science process skills are needed to get a product in knowledge (Zani et al., 2018).

The study results revealed that the use of an inquiry-based learning model was proven to be effective in increasing students' mastery of concepts (Pramudyawan et al., 2019). Student learning outcomes improved with the guided inquiry model than students who studied with conventional learning (Nurmayani et al., 2018). Increase student activity and creativity (A'yunin et al., 2016). Therefore, the application of the guided inquiry model can be used as a learning model to improve the Science Process Skills of high school students in the matter of work and energy.

\section{Method}

The research method used to answer this problem is the experimental method. The research design used is quasi-experimental. The population in this study was all class XI MIA SMA Negeri 5 Banda Aceh, which consisted of five parallel classes who took the science program in the even semester of 2020/2021 with 139 students. Two classes as research samples were selected by purposive sampling by taking into account the average value of physics for each class. Meanwhile, the determination of the experimental and control classes in this study was carried out randomly.

The type of instrument used is in the form of an observation sheet or an observation sheet. Observations were made with two observers at each meeting and were carried out when students were doing a practicum. Observation sheets are used to determine students' Science Process Skills on work and energy materials. Percentage tests are used in each group to analyze students' Process Science Skills and two different average tests of the Science Process Skills indicator are used for data analysis.

\section{Result and Discussion}

Data analysis of students' Science Process Skills on the work and energy material in the study was obtained by looking at the results of observations with two observers at each meeting and carried out when students did practicum. The experimental class used the guided inquiry model, while the control class used the Direct Interaction model. The results of the two mean 
difference tests that have been carried out can be seen in Table 1.

Table 1. The results of the two different test averages of the Science Process Skills indicators

\begin{tabular}{|c|c|}
\hline $\begin{array}{l}\text { Science Process } \\
\text { Skills Indicator }\end{array}$ & Significance* \\
\hline Observe & $\begin{array}{l}\mathrm{t}_{\text {count }}<\mathrm{t}_{\text {table }} \\
(3.17)>(1.68) \text { (Significantly Different) }\end{array}$ \\
\hline Classify & $\begin{array}{l}\mathrm{t}_{\text {count }}<\mathrm{t}_{\text {table }} \\
(0.30)<(1.68) \text { (Not Significantly Different) }\end{array}$ \\
\hline Predict & $\begin{array}{l}\mathrm{t}_{\text {count }}<\mathrm{t}_{\text {table }} \\
(3.52)>(1.68) \text { (Significantly Different) }\end{array}$ \\
\hline Measure & $\begin{array}{l}\mathrm{t}_{\text {count }}<\mathrm{t}_{\text {table }} \\
(4.27)>(1.68) \text { (Significantly Different) }\end{array}$ \\
\hline Communicating & $\begin{array}{l}\mathrm{t}_{\text {count }}<\mathrm{t}_{\text {table }} \\
(3.03)>(1.68) \text { (Significantly Different) }\end{array}$ \\
\hline Conclude & $\begin{array}{l}t_{\text {count }}<t_{\text {table }} \\
(4.14)>(1.68)(\text { Significantly Different })\end{array}$ \\
\hline
\end{tabular}

Description:

$*)=\mathrm{T}$ test (Significant, $\mathrm{t}$ count $<\mathrm{t}$ table, $=0.05$ )

The results of data analysis show that in general, there is a significant difference between the improvement of Science Process Skills in the experimental class and the control class for the indicators of observing, predicting, measuring, communicating, and concluding. However, for classifying indicators, the results were not significantly different. Analysis of Science Process Skills for each indicator was carried out in the experimental and control classes. The results can be seen in Table 2 .

Table 2. Percentage of observations of Science Process Skills

\begin{tabular}{lll}
\hline $\begin{array}{l}\text { Science Process Skills } \\
\text { Indicator }\end{array}$ & $\begin{array}{l}\text { Experiment } \\
\text { Class }\end{array}$ & $\begin{array}{l}\text { Control } \\
\text { Class }\end{array}$ \\
\hline Observation & 90.00 & 84.00 \\
Classification & 91.00 & 88.00 \\
Prediction & 93.00 & 86.00 \\
Measure & 94.00 & 85.00 \\
Communication & 92.00 & 86.00 \\
Conclude & 95.00 & 87.00 \\
\hline
\end{tabular}

The indicator observed in the experimental class obtained a score of $90 \%$. In the control class, a score of $84 \%$ was obtained. During the teaching and learning process, in accordance with the stages of the guided inquiry model, namely orientation. Where at this stage, the teacher prepares for learning, and at this stage, the teacher demonstrates an example of the effort and energy of students being required to be able to observe the demonstration that the teacher gives, and then students can also observe the problems contained in the Student Worksheet given by the teacher. While in the control class, the assessment of the observing indicator got the lowest score, this was because when the teacher who was demonstrating in front of the students was not so serious about paying attention to the teacher, it had an impact when students worked on the Student Worksheet given by the teacher.

Classifying indicators are indicators that have a low difference between the experimental class and the control class. Classifying indicators are skills to choose, compare, look for differences, find the basis for grouping. In guided inquiry learning, classifying indicators are developed at the data collection stage.

The stages of data collection that can develop classifying skills are by searching for various learning sources, then the results are discussed with discussion groups. According to Ratnasari et al. (2016), classification is a skill based on observing skills because it is based on observing skills which are basic science process skills. In the experimental class, according to the guided inquiry stage, students can formulate problems. The guided inquiry model trains students to formulate hypotheses because it is contained in the learning step at the stage of proposing observations to find problems where students are able to find and select information related to the problem.

At this stage, the experimental class students can also identify the response, control, and manipulation variables. The guided inquiry model requires students to be more active in learning or student-centered learning (Wenno et al., 2016). According to Derlina (2016), the guided inquiry model is a learning model that has a student-centered approach and can facilitate students to make observations. In the control class, the assessment on classifying indicators gets a score of $88 \%$. This is because the teacher plays an active role and provides information to students, so students no longer seek information about the given problem, so students cannot determine the response, control, and manipulation variables. In line with Iswatun et al. (2017), students are given the Direct Instruction learning model in the control class. This model does not present problems in learning, so students are not required to classify problems.

The indicator predicts that a score of $93 \%$ is obtained in the experimental class. In the control class, a score of $86 \%$ is obtained by the guided inquiry stage, namely formulating hypotheses. In the experimental class, students can write hypotheses or predict the problems written in the Student Worksheet, and in the experimental class, students can classify the related variables. Therefore, students in the experimental class were able to express how students did problem-solving. While in the control class, some students have not been able to write down their hypotheses on the problems contained in the Student Worksheet, and some students have not been able to determine the relationship between the three variables. This is because students in 
the control class were also unable to classify the three predetermined variables at the previous stage.

Indicators Measuring in the experimental class obtained a score of $94 \%$, while in the control class obtained a score of $85 \%$, in accordance with the stages of guided inquiry, namely collecting data. During the teaching and learning process, students can plan problem-solving at the measuring stage and prepare tools and materials needed in research. Students can also determine the ways and steps of working according to the worksheets given by the teacher, and students can measure the experiments contained in the Worksheet. Students with direction from the teacher are very enthusiastic about conducting experiments. Students can find solutions to problems from the experiments they have done, written in the form of reports. According to Rahmani et al. (2016), students' experiences when conducting experimental activities can foster their motivation to learn better so that science process skills can be achieved.

The indicator of communicating in the experimental class obtained a score of $92 \%$. In the control class, a score of $86 \%$ was obtained in accordance with the guided inquiry stage, namely, testing the hypothesis. At the stage of making a presentation, students in front of the class convey the results of group discussions to other groups. Students do questions and answers, express opinions if there are results obtained that are different from other groups. In this indicator, students are required to be able to communicate. This is in line with the opinion of Sakdiah et al. (2018), which states that students' communication skills can develop well if students carry out activities such as discussions.

The indicator concludes that the experimental class and control class get the highest score. A score of $95 \%$ is obtained. For the experimental and control classes, a score of $87 \%$ is obtained according to the stage of guided inquiry, namely, making conclusions. At the end of the teaching and learning process, students can draw about what they learned during the three meetings. It can be seen that students are very enthusiastic when the teacher asks students to conclude previous learning based on observations and facts.

The calculation picture of each indicator of Science Process Skills shows the differences in students' Science Process Skills between the experimental class and the control class. Students who were treated using the application of the guided inquiry model overall got a high category score. In the control class, there are indicators that are categorized as low.

The conclusion is that the model taught can improve students' Science Process Skills. It is in accordance with Iswatun et al. (2017), which states that the guided inquiry learning model can improve students' Science Process Skills. This model has a positive effect on science process skills and students' cognitive learning outcomes. According to Maharani et al. (2020), the guided inquiry learning stage consists of presenting problems, formulating hypotheses, designing experiments, carrying out experiments, collecting and analyzing data, and drawing conclusions. The stages in the guided inquiry model develop scientific methods in learning so that they can train Science Process Skills in students (Dewi et al., 2017).

\section{Conclusion}

Based on the analysis results, it can be concluded that there is a significant difference between experimental grade Science Process Skills and control class students. The Science Process Skills of the experimental class students who carried out the guided inquiry model showed better scores than the control class that carried out the Direct Instruction model, specifically on the concept of work and energy.

\section{References}

A'yunin, Q., Indrawati, \& Subiki. (2016). Penerapan model inkuiri terbimbing pada pembelajaran fisika materi listrik dinamis di SMK. Jurnal Pembelajaran Fisika, 5(2), 149-155. Retrieved from https://jurnal.unej.ac.id/index.php/JPF/article $\angle$ view/3962 [Indonesian]

Derlina. (2016). Efek Penggunaan Model Pembelajaran Inquiry Training Berbantuan Media Visual dan Kreativitas terhadap Keterampilan Proses Sains Siswa. Cakrawala Pendidikan, 35(2). doi:https://doi.org/10.21831/cp.v15i2.8080. [Indonesian]

Dewi, V.P., Doyan. A., \& Soeprianto, H. (2017). Pengaruh Model Penemuan Terbimbing Terhadap Keterampilan Proses Sains Ditinjau Dari Sikap Ilmiah Pada Pembelajaran IPA. Jurnal Penelitian Pendidikan IPA, 3(1), 60-67. doi:https://doi.org/10.29303/ippipa.v3i1.102 [Indonesian]

Dwianto, A., Wilujeng, I., Prasetyo, Z., \& Suryadarma, I. (2017). The Development of Science Domain Based Learning Tool Which is Integrated with Local Wisdom to Improve Science Process Skill and Scientific Attitude. Jurnal Pendidikan IPA Indonesia, $6(1)$. doi:https://doi.org/10.15294/ipii.v6i1.7205.

Gunawan, G., Harjono, A., Hermansyah, H., \& Herayanti, L. (2019). Guided Inquiry Model Through Virtual Laboratory To Enhance Students' Science Process Skills On Heat Concept. Cakrawala 
Pendidikan,

$38(2)$,

259-268.

doi:https://doi.org/10.21831/cp.v38i2.23345

Iswatun, I., Mosik, M., \& Subali, B. (2017). Penerapan model pembelajaran inkuiri terbimbing untuk meningkatkan KPS dan hasil belajar siswa SMP kelas VIII. Jurnal Inovasi Pendidikan IPA, 3(2), 150160.

doi:https://doi.org/10.21831/jipi.v3i2.14871. [Indonesian]

Lestari, M.Y., \& Diana, N. (2018). Keterampilan Proses Sains (KPS) Pada Pelaksanaan Praktikum Fisika Dasar I. Indonesian Journal of Science and Mathematics Education, 01(1), 49-54. doi: https://doi.org/10.24042/ijsme.v1i1.2474 [Indonesian]

Maharani, R., Taufik, M., Ayub, S., \& Rokhmat, J. (2020). Pengaruh Model Pembelajaran Inkuiri dengan Bantuan Media Tiga Dimensi Terhadap Keterampilan Proses Sains dan Hasil Belajar Fisika Peserta Didik. Jurnal Penelitian Pendidikan IPA, 6(1), 113-118. doi:https:// doi.org/10.29303/jppipa.v6i1.326. [Indonesian]

Nurmayani, L. Doyan, A. \& Verawati, N.N.S.P. (2018). Pengaruh Model Pembelajaran Inkuiri Terbimbing Terhadap Hasil Belajar Fisika Peserta Didik. Jurnal Penelitian Pendidikan IPA, 4(2), 23-28. doi: https://doi.org/10.29303/jppipa.v4i2.113 [Indonesian]

Pramudyawan, M., Doyan, A., \& 'Ardhuha, J. (2020). Pengaruh Model Pembelajaran Inkuiri Terbimbing Berbantuan Kit Alat Percobaan Usaha dan Energi terhadap Penguasaan Konsep Fisika Peserta didik. Jurnal Penelitian Pendidikan IPA, 6(1), $\quad$ 40-44. doi:https://doi.org/10.29303/jppipa.v6i1.290. [Indonesian]

Rahmani, R., Halim, A., \& Jalil, Z. (2016). Penerapan Model Pembelajaran Inkuiri Terbimbing Untuk Meningkatkan Keterampilan Proses Sains (KPS) Siswa Sekolah Dasar. Jurnal Pencerahan, 10(2), 7480. doi: https://doi.org/10.13170/jp.10.2.5213 [Indonesian]

Ratnasari, G. G., \& Supriyanti, F.M.T. (2016). Profil Keterampilan Proses Sains Siswa SMA pada Pembelajaran Termokimia Menggunakan Model Inkuiri Terbimbing. Jurnal Riset dan Praktik Pendidikan Kimia, 4(1), 61-69. [Indonesian]

Rosidin, U., Kadaritna, N., \& Hasnunidah, N. (2019). Can Argument-Driven Inquiry Models Have Impact On Critical Thinking Skills For Students With Different Personality Types?. Cakrawala Pendidikan, 38(3), 511-526. doi:https:// doi.org/10.21831/cp.v38i3.24725.
Sakdiah., Mursal., \& Syukri, M. (2018). Penerapan Model Inkuiri Terbimbing untuk Meningkatkan Pemahaman Konsep dan KPS Pada Materi Listrik Dinamis Siswa SMP. Jurnal IPA dan Pembelajaran IPA, 2(1), 41-49. doi: https://doi.org/10.24815/jipi.v2i1.10727 [Indonesian]

Haerani, S., Doyan, A., \& Taufik, M. (2021). Development of Guided Inquiry Model Tools Assisted Palm Fiber Composite Media in Sound Wave Material. Jurnal Penelitian Pendidikan IPA, $7(2)$, 149-155. doi:https://doi.org/10.29303/jppipa.v7i2.562.

Wahyuni, S., Indrawati, I., Sudarti, S., \& Suana, W. (2017). Developing Science Process Skills and Problem Solving Abilities Based on Outdoor Learning in Junior High School. Jurnal Pendidikan IPA Indonesia, 6(1). doi:https:// doi.org/10.15294/jpii.v6i1.6849.

Wenno, I., Esomar, K., \& Sopacua, V. (2016). Analisis Kesulitan Belajar Dan Pencapaian Hasil Belajar Siswa Melalui Strategi Pembelajaran Inkuiri. Cakrawala Pendidikan, 35(3). doi:https://doi.org/10.21831/cp.v35i3.10706. [Indonesian]

Zani, R., Adlim., \& Safitri, R. (2018). Penerapan Model Pembelajaran Inkuiri Terbimbing pada Materi Fluida Statis untuk meningkatkan Hasil Belajar dan Keterampilan Proses Sains Siswa. Jurnal IPA dan Pembelajaran IPA (JIPI), 2(2), 56-63. doi: https://doi.org/10.24815/jipi.v2i2.11622 [Indonesian] 